\begin{tabular}{|c|c|c|}
\hline & Int.J.Curr.Microbiol.App.Sci (2016) 5(3): 107-113 & \\
\hline & International Journal of Current Microbiology and Applied Sciences & 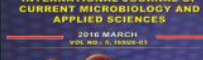 \\
\hline & ISSN: 2319-7706 Volume 5 Number 3(2016) pp. 107-113 & \\
\hline $\begin{array}{l}\text { EXCELLENT } \\
\text { PUBLISHERS }\end{array}$ & & \\
\hline PUBLISHERS & & wwrwijemas.com \\
\hline
\end{tabular}

Original Research Article

http://dx.doi.org/10.20546/ijcmas.2016.503.015

\title{
Impact of Urban Air Pollution on Photosynthetic Pigment and Proline Content of Plants Growing along the A.B road Indore City, India
}

\author{
S. Patidar ${ }^{1}$, A. Bafna ${ }^{1 *}$, A.R. Batham ${ }^{1}$ and K. Panwar ${ }^{2}$ \\ ${ }^{1}$ Department of Biochemistry, Govt. Holkar Science College, Indore-452017, MP, India \\ ${ }^{2}$ Department of Botany, Govt. Holkar Science College, Indore-452017, MP, India \\ *Corresponding author
}

\begin{abstract}
A B S T R A C T
Keywords

A.B road, T.neriifolia, M. indica, P.guajava, Vehicular pollution.

\section{Article Info}

Accepted:

12 February 2016

Available Online:

10, March 2016

Air pollution is a worldwide problem. Screening of plants for their sensitivity/tolerance level to air pollutants is important because the sensitive plants can serve as bio-indicator and the tolerant plants can resist air pollution in urban and industrial areas. The present study was carried out with the aim that A.B road of Indore city (MP) is heavily polluted due to enormous increase in vehicle numbers. The present study was done by selecting five heavily polluted sites of the Agra-Bombay highway (NH-3). Thevetia neriifolia (kaner), Magnifera indica (Aam), Psidium guajava (Jam) plants growing along the A.B road were selected. Chlorophyll and Proline content of leaves of the selected plants from the selected sites were analyzed. At most of the sites chlorophyll content was decreased in the leaves of the studied plants when compared with the plants of reference site. Maximum reduction in Chlorophyll-a, Chlorophyll-b and total Chlorophyll were observed in leaves of $M$. indica at LIG square. Proline content was increased when compared with the reference site. Maximum increase in Proline content $(\uparrow 340 \%)$ was observed in leaves of $M$. indica at LIG square polluted site. It was concluded that these parameters are highly significant in understanding the plant-environment interactions and are used for developing of bio-indicator groups.
\end{abstract}

\section{Introduction}

Air pollution may be broadly defined as the presence of one or more contaminants like dust, smoke, and many kinds of air pollutants which are injurious to human being, crops and plants. Air pollutants are gaseous and particulates in nature. Gaseous air pollutants are absorbed by leaves through stomata, while particulates get deposited on their surfaces. Over the years, there has been a continuous increase in human population, road transportation, vehicular traffic and industries which has resulted in further increase in the concentration of gaseous and particulate pollutants on plants (Joshi et al., 2009). Indore is the commercial capital of Madhya Pradesh with a population of over 3,276,697 lakh and Density 839 per Sq. Km. (Reported in the year 2011). Automobile exhaust emission with high traffic density in urban areas has been also leading to increase air pollution (Rai and Mishra 2013). Plants 
growing along road sides are exposed to pollutants emitted from automobiles. Plants have a very large surface area and their leaves function as an efficient pollutant trapping device (Sirajuddin et al., 2012). The use of plants as biomonitor of air pollution has long been established as plants are the initial acceptors of air pollutant. Chlorophyll is the principal photoreceptor in photosynthesis. One of the most common impacts of air pollution is the gradual disappearance of chlorophyll and concomitant yellowing of leaves, which may be associated with a consequent decrease in the capacity for photosynthesis (Joshi and Swami, 2007). Existence of $\mathrm{SO}_{2}$, Carbon monoxide and other pollutant in the air content of vehicular traffic increase the Proline content of plants. Proline is of special interest because of its extensive accumulation in plants during environmental stress (Wang et al., 2009). The present analysis was intended to reveal the two parameters chlorophyll and proline content which indicate the effects of air pollution on plant's leaves in Indore.

\section{Materials and Methods}

The experimental work of the study was carried out in the laboratory of Department of Biochemistry, Govt. Holkar Science College, Indore, Six locations- One as Reference site and five as polluted site of A.B Road were selected which were visited randomly. Observations were made through transects each of $500 \mathrm{~m}$ length with 5-10 m on either side.

\section{Sample Collection}

\section{Refrence site}

Ref. - DAVV, Khandwa road

\section{Five polluted sites}

\section{P.1 - Bhawarkunwa square}

P.2 - Navlakha Square

P.3 - Geetabhawan square

P.4 - Palasia Square

P.5 - LIG square

\section{Plant used for study}

1. Thevetia neriifolia (kaner)

2. Magnifera indica (Aam)

3. Psidium guajava (Jam)

Matured leaves from each matured plants were collected for analysis and immediately placed in labeled plastic packet for laboratory testing.

\section{Biochemical Parameters}

After collection of leaves the tissue homogenate was prepared and centrifuged at different rpm and analysis of Chlorophyll and Proline content was done.

\section{Estimation of Chlorophyll}

The amount of chlorophyll i.e. Chlorophyll a, Chlorophyll b and total Chlorophyll was calculated according to Arnon 1949 by using following formula-

Chlorophyll (a) in $\mathrm{mg} / \mathrm{g}$ tissue $=12.7\left(\mathrm{~A}_{663}\right)$ - $2.69(\mathrm{~A} 645) \times \mathrm{V} / 1000 \times \mathrm{W}$

Chlorophyll $(\mathrm{b})$ in $\mathrm{mg} / \mathrm{g}$ tissue $=22.9\left(\mathrm{~A}_{645}\right)$ - $4.68\left(\mathrm{~A}_{663}\right) \times \mathrm{V} / 1000 \times \mathrm{W}$

Total chlorophyll $(\mathrm{mg}$ per $\mathrm{g}$ tissue $)=20.2$ $\left(\mathrm{A}_{645}\right)+8.02\left(\mathrm{~A}_{663}\right) \times \mathrm{V} / 1000 \times \mathrm{W}$

\section{Estimation of Proline}

It was estimated with Ninhydrin in acidic solution ( $\mathrm{pH}-1.0)$ to form the chromophore (Sadasivam and Manikam 1992) by using following formula- 
$\mu$ moles per $\mathrm{g}$ tissue $=\mu \mathrm{g}$ Proline $/ \mathrm{ml} \times \mathrm{ml}$ toluene/115.5x 5/gm of sample

Where 115.5 is the molecular weight of Proline.

\section{Results and Discussion}

The present study results showed impact of vehicular pollution on the plants growing along the road. As shown in table1chlorophyll content in the leaves of all the studied plants was decreased at all the polluted sites except at site-1 in Thevetia neriifolia. This revealed that chlorophyll contents in all the plants varies with the pollution status of the site i.e. higher the Pollution level in the form of vehicular exhausts lower the chlorophyll content.

In Thevetia neriifolia highly significant $(\mathrm{p}<0.001)$ increase in chlorophyll-a and total chlorophyll content was observed at Polluted site-1.This increased chlorophyll content may be due to shading effect. The result of present study is supported by the study of Agbaire and Esiefarienrhe, 2009.

At the remaining polluted site in all the studied plants, highly significant $(\mathrm{p}<0.001)$ decrease in chlorophyll-a, chlorophyll-b and total chlorophyll content of leaves was observed. Maximum reduction in Chlorophyll-a (27\%), in chlorophyll-b $(31.10 \%)$ and total chlorophyll (30.42\%) was seen in Magnifera indica at polluted site-5. Chlorophyll content varies with the tolerance as well as sensitivity of the plant species i.e. higher the sensitive nature of the plant species lower the chlorophyll content. High levels of automobile pollution decreases chlorophyll content in higher plants near roadsides (Chandawat et al., 2011; Adamsab et al., 2011).

The results of present study are supported by the work of Chauhan et al., 2011; Joshi and
Swami, 2009. The reduction in chlorophyll content may be due to the $\mathrm{SO}_{2}$ induced activity resulting in removal of $\mathrm{Mg}^{++}$ions, which convert it into pheophytin. (Qayoommir et al., 2008).While Minimum reduction in chlorophyll-a (14.2\%), chlorophyll-b (6.06\%) and total chlorophyll $(5.35 \%)$ content was observed in Thevetia neriifolia at Polluted site-2.

In present study highly significant level of Proline was observed in the leaves of all studied plants and the maximum increase (340\%) was found in Magnifera indica at polluted site-5 which is supported by the work of Wang et al., 2009, High exposure to vehicular pollutants forces chloroplasts into an excessive excitation energy level, which in turn increases the generation of ROS and induces oxidative stress (Woo et al., 2007).

The deleterious effects of the vehicular pollutants are caused by the production of Reactive Oxygen Species (ROS) in plants, which results in peroxidative destruction of cellular constituents (Tiwari et al., 2006). It has been reported that proline act as a free radical scavenger to protect plants away from damage by oxidative stress. Obviously proline has main role in protection in different kinds of stress. Accumulation of proline in plants is a physiological response to osmotic stress (Szekely, 2004).In the present study significant negative correlation of chlorophyll-a, chlorophyll-b and total chlorophyll with proline was observed in the all the studied plants. The decrease in chlorophyll content under vehicle pollution stress is mainly the result of damage to chloroplast caused by active oxygen species. Plants try to protect themselves against stress created by vehicular pollutants. Proline is one of the most common compatible osmolyte, which helps the plant to survive under stress. Increased proline content can be use as a marker of vehicular pollution. 
Table.1 Showing Values of Chlorophyll a, Chlorophyll b and Total Chlorophyll in $\mathrm{mg} / \mathrm{g}$ of Leaves of Plants at Reference vs. Polluted Sites

\begin{tabular}{|c|c|c|c|c|}
\hline \multirow{2}{*}{$\begin{array}{l}\text { Studied } \\
\text { sites }\end{array}$} & Plants & \multirow[t]{2}{*}{ T.neriifolia } & \multirow[t]{2}{*}{ M.indica } & \multirow[t]{2}{*}{ P.guajava } \\
\hline & neters & & & \\
\hline \multirow{3}{*}{$\begin{array}{l}\text { Reference } \\
\text { site }\end{array}$} & Chl. a & $6.02 \pm .04$ & $5.0 \pm .03$ & $7.1 \pm .03$ \\
\hline & Chl. b & $4.95 \pm .02$ & $6.88 \pm .03$ & $8.2 \pm .03$ \\
\hline & Total chl. & $4.48 \pm .02$ & $6.08 \pm .03$ & $5.98 \pm .03$ \\
\hline \multirow{3}{*}{$\begin{array}{l}\text { Polluted } \\
\text { Site -1 }\end{array}$} & Chl. a & $5.25 \pm .01 *(\downarrow 12.79 \%)$ & $4.11 \pm .01 *(\downarrow 17.8 \%)$ & $6.34 \pm .01 *(\downarrow 10.70 \%)$ \\
\hline & Chl. b & $5.81 \pm .05 *(\uparrow 17.37 \%)$ & $5.63 \pm .02 *(\downarrow 18.16 \%)$ & $6.60 \pm .02 *(\downarrow 19.51 \%)$ \\
\hline & Total chl. & $5.18 \pm .02 *(\uparrow 15.62 \%)$ & $4.79 \pm .04 *(\downarrow 21.21 \%)$ & $5.43 \pm .02 *(\downarrow 9.19 \%)$ \\
\hline \multirow{3}{*}{$\begin{array}{l}\text { Polluted } \\
\text { Site -2 }\end{array}$} & Chl. a & $5.19 \pm .09 *(\downarrow 14.2 \%)$ & $3.92 \pm .07 * \downarrow(21.6 \%)$ & $6.1 \pm .02 *(\downarrow 14.08 \%)$ \\
\hline & Chl. b & $4.65 \pm .08 *(\downarrow 6.06 \%)$ & $5.12 \pm .02 *(\downarrow 25.58 \%)$ & $6.22 \pm .02 *(\downarrow 24.14 \%)$ \\
\hline & Total chl. & $4.24 \pm .03 *(\downarrow 5.35 \%)$ & $4.72 \pm .04 *(\downarrow 22.36 \%)$ & $5.43 \pm .02 *(\downarrow 9.19 \%)$ \\
\hline \multirow{3}{*}{$\begin{array}{l}\text { Polluted } \\
\text { Site -3 } \\
\end{array}$} & Chl. a & $5.15 \pm .05 *(\downarrow 14.45 \%)$ & $3.79 \pm .01 *(\downarrow 24.2 \%)$ & $5.27 \pm .01 *(\downarrow 10.45 \%)$ \\
\hline & Chl. b & $4.61 \pm .03 *(\downarrow 6.86 \%)$ & $5.23 \pm .04 *(\downarrow 23.98 \%)$ & $6.3 \pm .03 *(\downarrow 23.17 \%)$ \\
\hline & Total chl. & $4.17 \pm .02 *(\downarrow 6.91 \%)$ & $4.69 \pm .02 *(\downarrow 22.86 \%)$ & $4.70 \pm .03 *(\downarrow 21.40 \%)$ \\
\hline \multirow{3}{*}{$\begin{array}{l}\text { Polluted } \\
\text { Site -4 }\end{array}$} & Chl. a & $4.9 \pm .03 *(\downarrow 18.63 \%)$ & $3.77 \pm .08 *(\downarrow 24.6 \%)$ & $5.82 \pm .01 *(\downarrow 24.39 \%)$ \\
\hline & Chl. b & $4.63 \pm .03 *(\downarrow 6.46 \%)$ & $4.80 \pm .03 *(\downarrow 30.23 \%)$ & $6.15 \pm .02 *(\downarrow 25 \%)$ \\
\hline & Total chl. & $4.19 \pm .03 *(\downarrow 6.47 \%)$ & $4.74 \pm .0 *(\downarrow 22.03 \%)$ & $4.24 \pm .02 *(\downarrow 29.09 \%)$ \\
\hline \multirow{3}{*}{$\begin{array}{l}\text { Polluted } \\
\text { Site -5 }\end{array}$} & Chl. a & $4.77 \pm .02 *(\downarrow 20.76 \%)$ & $3.65 \pm .01 *(\downarrow 27.0 \%)$ & $5.17 \pm .02 *(\downarrow 25.93 \%)$ \\
\hline & Chl. b & $4.60 \pm .05 *(\downarrow 7.07 \%)$ & $4.74 \pm .06 *(\downarrow 31.10 \%)$ & $6.32 \pm .03 *(\downarrow 22.92 \%)$ \\
\hline & Total chl. & $4.15 \pm .05 *(\downarrow 7.36 \%)$ & $4.23 \pm .03 *(\downarrow 30.42 \%)$ & $4.19 \pm .03 *(\downarrow 29.93 \%)$ \\
\hline
\end{tabular}

Note - Parentheses - \% increase/decrease. *Indicates p value $<0.001$ and is highly significant compared to control.

Table.2 Showing Proline Content ( $\mu$ mole/gm) in Leaves of Studied Plants in Reference vs. Polluted Sites

\begin{tabular}{|c|c|c|c|c|c|c|}
\hline \multirow[b]{2}{*}{ Plants } & \multirow{2}{*}{$\begin{array}{l}\text { Reference } \\
\text { site }\end{array}$} & \multicolumn{5}{|c|}{ Polluted sites } \\
\hline & & Site-1 & Site-2 & Site-3 & Site-4 & Site-5 \\
\hline T.ne & $1.40 \pm .01$ & $\begin{array}{c}1.73 \pm .03 * \\
(23.5 \%) \uparrow\end{array}$ & $\begin{array}{c}2.02 \pm .02 * * \\
(44.2 \%) \uparrow\end{array}$ & $\begin{array}{c}3.04 \pm .02 * * \\
(117 \%) \uparrow\end{array}$ & $\begin{array}{c}2.82 \pm .01 * * \\
(101.4 \%) \uparrow\end{array}$ & $\begin{array}{c}2.90 \pm .07 * * \\
(107.1 \%) \uparrow\end{array}$ \\
\hline M. indica & $0.37 \pm .05$ & $\begin{array}{c}0.40 \pm .02^{(\mathrm{NS})} \\
(8.1 \%) \uparrow \\
\end{array}$ & $\begin{array}{c}0.96 \pm .02 * \\
(140 \%) \uparrow\end{array}$ & $\begin{array}{c}1.47 \pm .02 * * \\
(267.5 \%) \uparrow\end{array}$ & $\begin{array}{l}1.60 \pm .01 * * \\
(300 \%) \uparrow\end{array}$ & $\begin{array}{c}1.76 \pm .02 * * * \\
(340 \%) \uparrow\end{array}$ \\
\hline P. guajava & $1.03 \pm .01$ & $\begin{array}{c}1.23 \pm .03 * \\
(13.88 \%) \uparrow\end{array}$ & $\begin{array}{c}1.08 \pm .01 * \\
(4.8 \%) \uparrow\end{array}$ & $\begin{array}{c}1.66 \pm .06 * * \\
(53.7 \%) \uparrow\end{array}$ & $\begin{array}{c}2.01 \pm .01 * * \\
(86.11 \%) \uparrow\end{array}$ & $\begin{array}{c}2.15 \pm .02 * * \\
(99.07 \%) \uparrow\end{array}$ \\
\hline
\end{tabular}

Note: -Parentheses - \% increase. *Indicates p value $<0.001$ and change is high significant compared to control, ${ }^{\mathrm{NS}}$ indicates $P$ value $>0.05$, insignificant as compared to control

Table.3 Showing Correlation Coefficient of Chlorophyll-A, Chlorophyll -B and Total Chlorophyll with Proline Content in Studied Plants

\begin{tabular}{|c|c|c|c|}
\hline Covariance/Plant & T.neriifolia & M.indica & P. guajava \\
\hline Chlorophyll a with Proline & $\mathbf{- 0 . 8 0 6 6 6}$ & $\mathbf{- 0 . 8 0 4 7}$ & $\mathbf{- 0 . 8 0 0 1 9}$ \\
\hline Chlorophyll b with Proline & $\mathbf{- 0 . 6 2 2 6 4}$ & $\mathbf{- 0 . 8 0 9 1 6}$ & $\mathbf{- 0 . 5 5 6 7 8}$ \\
\hline $\begin{array}{c}\text { Total Chlorophyll with } \\
\text { Proline }\end{array}$ & $\mathbf{- 0 . 6 5 2 0 2}$ & $\mathbf{- 0 . 7 1 2 9 4}$ & $\mathbf{- 0 . 9 7 3 6 1}$ \\
\hline
\end{tabular}


Figure.1 Chlorophyll Content (mg/gm) in Leaves of T. neriifolia Reference vs. Polluted Site

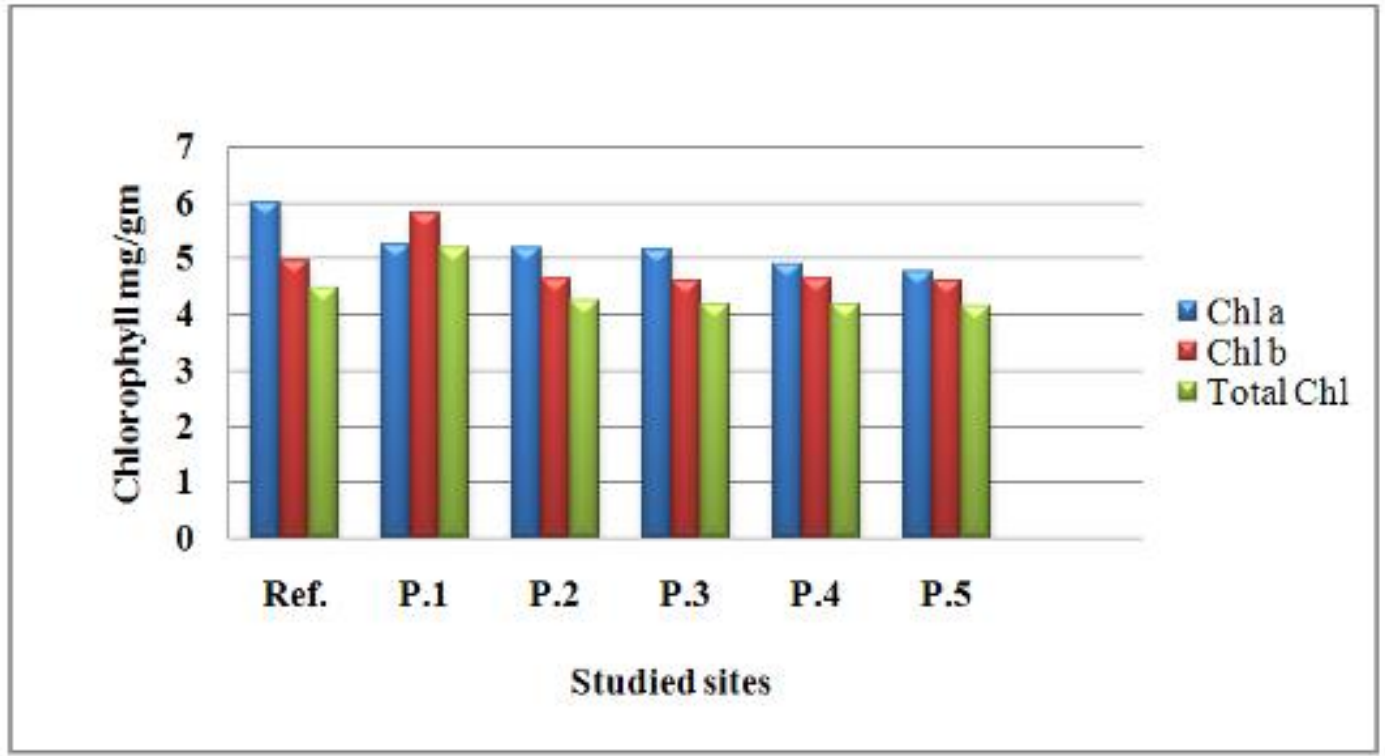

Figure.2 Chlorophyll Content (mg/gm) in Leaves of M.indica Reference vs. Polluted Site

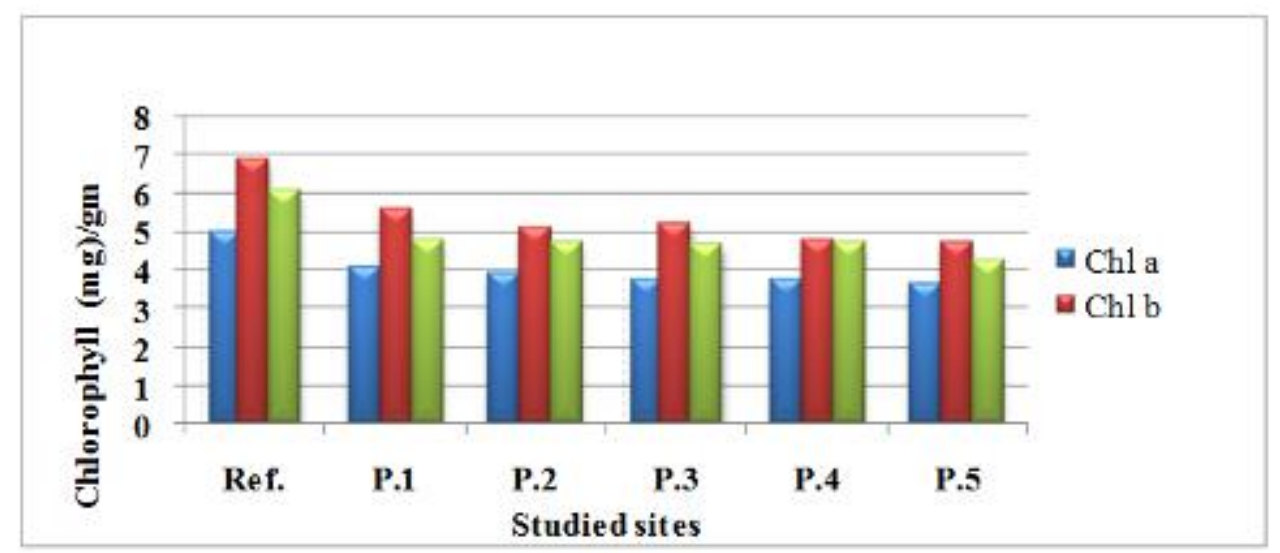

Figure.3 Chlorophyll Content (mg/gm) in Leaves of P. guajava Control vs. Polluted Site

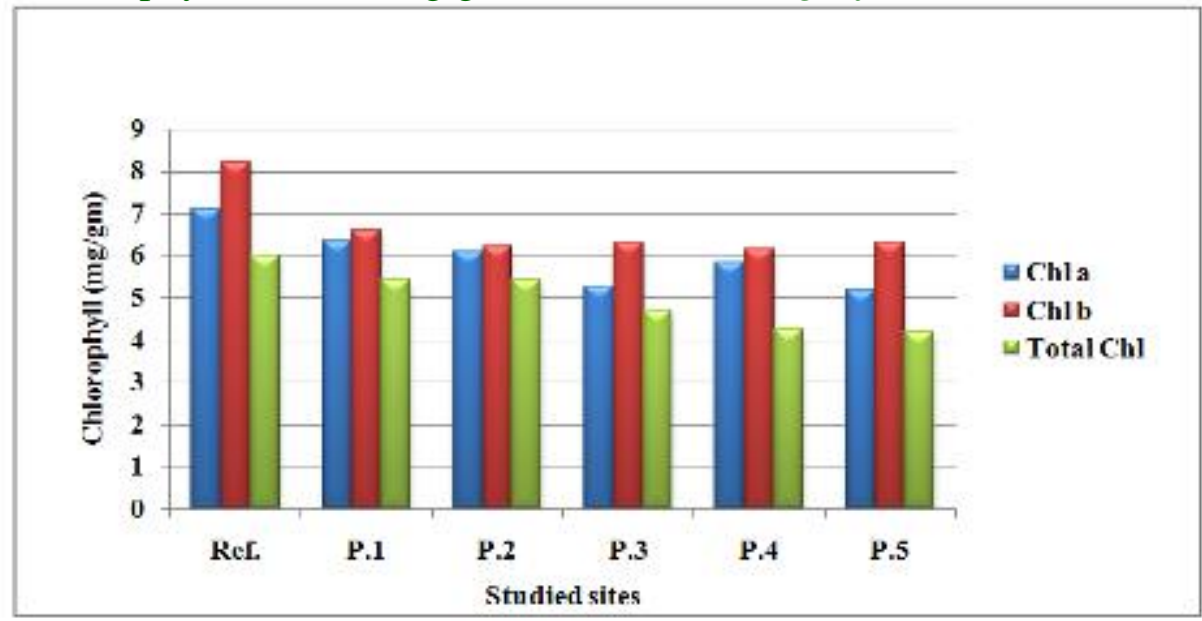


Figure.4 Comparision of Total Chlorophyll Among the Studied Plants at Reference Vs Polluted Sites

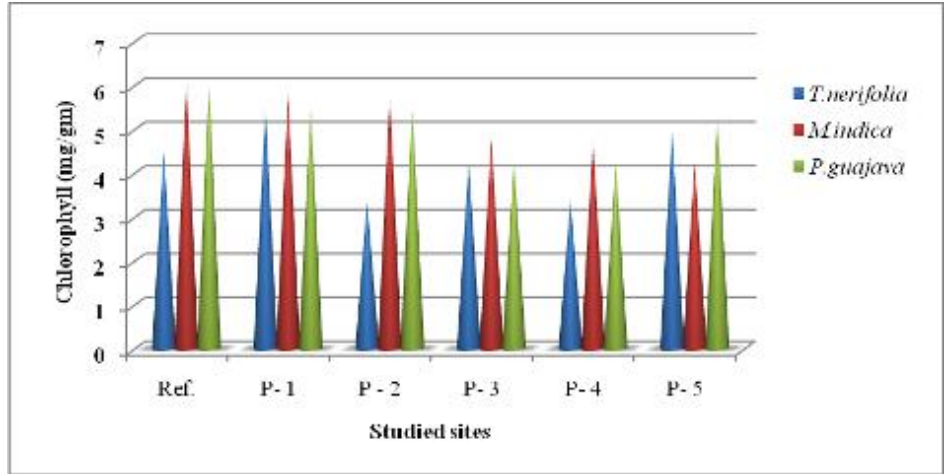

Figure.5 Proline Content ( $\mu$ mole/gm) in Leaves of studied Plants Reference vs. Polluted Sites

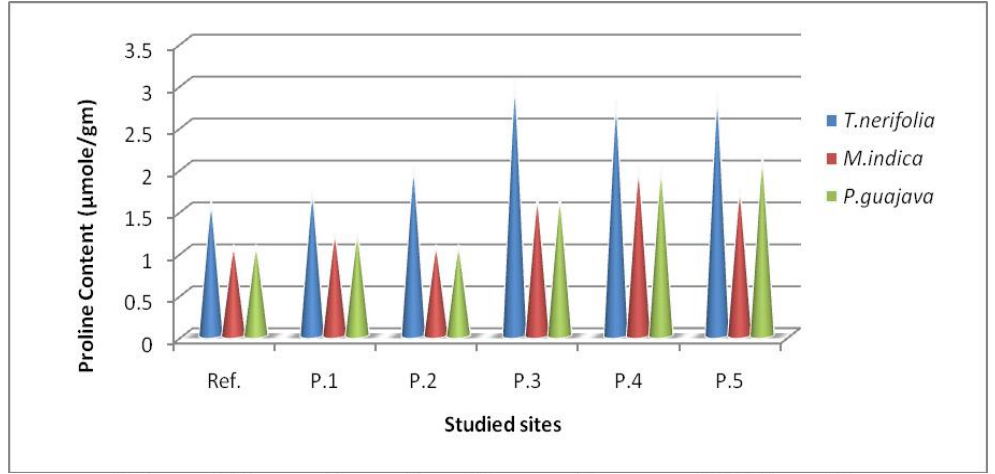

Map Showing the Locations of Sites for Collection of Leaf Sample

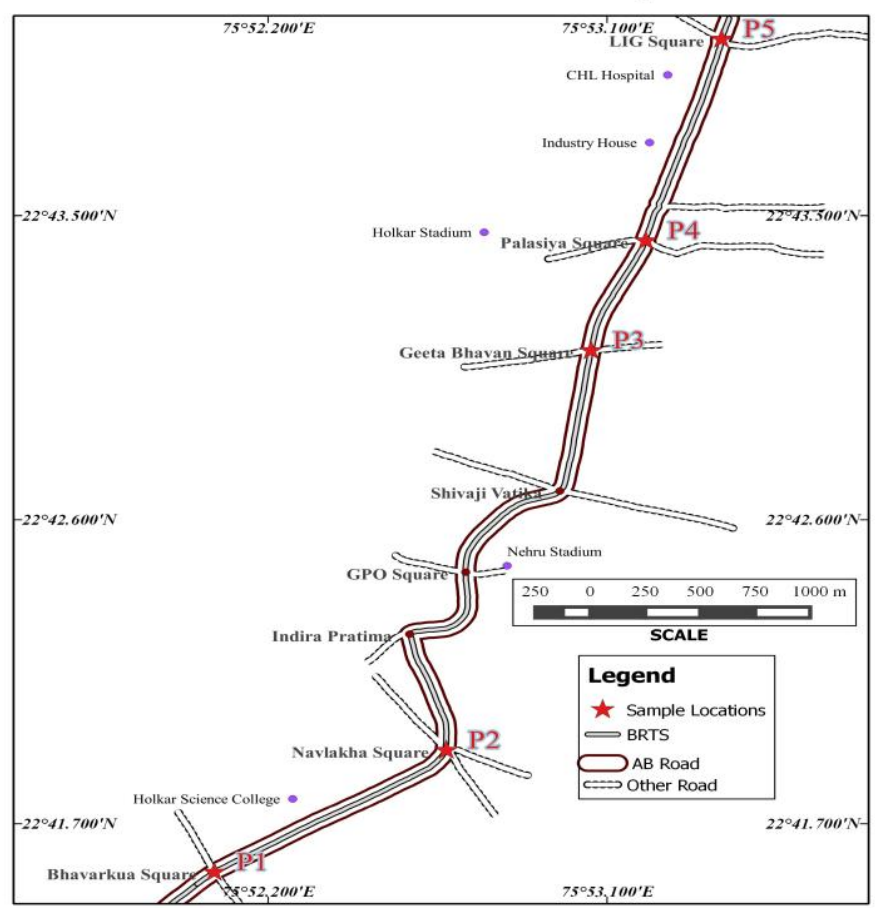

It can be concluded that the Vehicular pollutants affects photosynthesis and cause oxidative stress in the plants. Magnifera indica was found to be very sensitive 
towards the air pollutants while the Thevetia neriifolia was resistant and can tolerate vehicular pollution. Thus the present study suggested that the Thevetia neriifolia should be planted along the heavily polluted road side while the Magnifera indica should be planted away from the road side. Vegetation naturally cleanses the atmosphere by absorbing gases and some particulate matter through leaves. Magnifera indica species work as sink of air pollutants.

\section{Acknowledgement}

We express our sincere thanks to Dr K.N. Chaturvedi, Principal and Prof. R.S. Maheshwari, Head of Department of Biochemistry, S.K Chore and Bharat Porwal, Department of Geology Government Holkar Science College Indore (M.P.) for providing necessary laboratory facilities and encouragement.

\section{References}

Deepalakshmi, A.P., Ramakrishnaiah, H., et al., 2013. Roadside Plants as Bio-indicators of Urban Air Pollution (IOSR -JESTFT) e ISSN: 2319-2402, p-ISSN: 23192399.Vol.3(3): 10-14.

Adamsab, M., Patel, Kousar, H., Sirajuddin, M.H. 2011. APTI of Some Selected Plants in Shivamogga City, South Asia.The International Conference on Advanced Science, Engineering and Information Technology (ICASEIT), 9: 668-670.

Agbaire, P.O., Esiefarienrhe, E. 2009. Air Pollution Tolerance Indices (APTI) of some plants around Otorogun gas plant in Delta state, Nigeria. J. App. Sci. Environ. Manage., 13: 11-14.

Chandawat, D.K., Verma, P.U., Solanki, H.A. 2011. Air pollution Tolerance Index (APTI) of Tree Species at cross road of Ahmedabad city, Life science. Leaflets., 20: 935-943.

Chauhan, A., Bafna, A. 2011. Study of effect of air pollution on photosynthetic pigment of some plants growing in pithampur industrial area, dhar (M.P.) Int. J. Cur. Sci. Res., 1(4): $187-190$.

Joshi, P.C., Swami, A. 2007. Physiologigal responses of some tree species under roadside automobile pollution stress around city of Haridwar, India Environmentalist., (27): 365-374.

Joshi, P.C., Swami, A. 2009. Air pollution induced changes in the photosynthetic pigments of selected plant species. $J$. Environ. Boil., (30): 295-298.

Rai, P., Mishra, R.M. 2013. Effect of urban air pollution on epidermal traits of road side tree species, Pongamia pinnata (L.) Merr. (IOSR-JESTFT) e-ISSN: 2319-2402, pISSN: 2319-2399, 2(6): 4-7.

Sirajuddin, M. H., Ravichandran, M., Abdul Samad, M.K. 2012. Air Pollution Tolerance of Selected Plant Species Considered for Urban Green Belt Development in Trichy. World J. Environ. Biosci., (1): 51-54.

Wang, F., Zeng, B., Sun, Z., Zhu, C. 2009. Relationship between proline and $\mathrm{Hg}^{2+}$ induced oxidative stress in a tolerant rice mutant. Arch. Environ. Contam. Toxicol. (56): 723-731.

Woo, S.Y., Lee, D.K., Lee, Y.K. 2007. Net photosynthetic rate, ascorbate peroxidase and glutathione reductase activities of Erythrina orientalis in polluted and nonpolluted areas. Photosynthetica, (45): 293295.

\section{How to cite this article:}

Patidar, S., Bafna, A., Batham' A.R., Panwar, K. 2016. Impact of Urban Air Pollution on

Photosynthetic Pigment and Proline Content of Plants Growing along the A.B road Indore City, India. Int.J.Curr.Microbiol.App.Sci. 5(3): 107-113.

doi: http://dx.doi.org/10.20546/ijcmas.2016.503.015 